\title{
The East Galician Zionist Federation AND The Polish Governments of 1922-1926
}

\author{
Nadia Skokova \\ (Ukrainian Catholic University in Lviv, Ukraine) \\ e-mail: nadiaskokova@email.ua
}

Keywords: state nationalism, national minority nationalism, economic crisis, political discourse, Galician Zionist

\begin{abstract}
The fledgling processes of the single-state governmental system of the reborn Polish state in 1920 were intended to deal with many current challenges and historical backgrounds. The article analyses the causes and different contexts and conditions which were forged to initiate the Polish-Jewish negotiations of 1925. The primary attention is focused on the solutions to the economic crisis and its consequences. Also, we consider the in-house situation between different factions in the Jewish Club to better understand all the pros and cons that made the future agreements possible.

To provide such analysis of the Polish-Jewish negotiations, we use the Rogers Brubaker's nationalising approach, which lets us examine the interactions between the Polish state nationalism and the nationalism of East Galician Zionists. We also apply multiple situational analysis to investigate the ample variety of reasons behind those negotiations. This approach allowed us to consider the 1925 Agreement in the broad geopolitical context in which both sides were interested.
\end{abstract}

The reborn Polish state did not have much power: its governments changed frequently, and a clear state policy on many socio-cultural aspects of a multinational country did not exist. After signing Treaty of Versailles in 1919, the Polish state was convinced that it had been unfairly dealt with as a young state entity. This approach served as a justification of ethnic politics pursued by governments and formed the basis of the influential rhetoric of the National Democrats.

Although in historiography the relationship between Polish governments and the rights and self-determination of national minorities is one of the most critical aspects, researchers always strive to demonstrate the cause-and-effect results of the government's national policy and responses to restrictions imposed on national minorities. However, the history of the Zionist Organization in Eastern Galicia (ZO of East Galicia), whose political tactics, formed under the conditions of the Austrian liberal climate, were intended to seek potential compromises instead of radically confronting the governmental policy for the sake of improving the living conditions of the Jewish population.

For these reasons this article will analyse the conditions which made it possible to sign the Polish-Jewish agreement in 1925. I will also try to show the mutual influence of representatives of two nationalisms, both Jewish and Polish: the Jewish Club and Polish 
governments, whose interests intersected in spheres important to both sides. The main emphasis was placed on the economic crisis and its impact on the political situation in interwar Poland. In terms of chronology, the text covers 1922-1925, when the Lviv Zionists outnumbered the Jewish Club and had real influence over the talks. During the subsequent period (1926-1939), the Warsaw Zionists gained the political advantage, as Galician Jews concentrated on the expansion of Jewish communities in three Galician provinces.

We used Rogers Brubaker's ${ }^{1}$ approach to highlight the process of communication and mutual seeking of political balance between two different political actors - the Polish government with its own nationalist interests on one hand and the nationalist Jewish minority on the other. In this article, we focus more precisely on political and geopolitical aspects, which had their own influence on the Polish nation-building and the Jewish national revival of the $1920 \mathrm{~s}$. We also used a multi-faceted analysis to understand what conditions brought the Jewish Club closer to the government of Władysław Grabski.

In contemporary historiography, no attempt has been made to show the mutual influences of Polish and Jewish nationalism. However, influential works well describe the political, economic and parliamentary situation in the country in the 1920s. It is worth mentioning Antony Polonsky and his political synthesis of Polish history. ${ }^{2}$ Wojciech Jaworski was the first to describe the activity of the Jewish Club, ${ }^{3}$ and Ezra Mendelsohn explored the foundations of political Zionism and its most important stages of development. $^{4}$

\section{The 1922 elections and their results}

When the Polish delegation at the Paris Peace Conference of 1919-1920 signed an agreement on the national and cultural autonomy of national minorities, it looked like a victory for Galician Jews. Thanks to the efforts of the East Galician delegation at the peace conference and the activity of the Viennese branch of the Jewish National Councils and numerous international delegations in Galicia, it was possible to disseminate information about the Jewish pogroms of 1918-1919. These pogroms set a precedent for the creation of an agreement on the rights of national minorities that was to resolve disputed territorial claims that were not included in Woodrow Wilson's 14 Points.

However, on the other hand, the Galician Zionists were in no hurry to take an active part in the political life of the new Polish state or the 1922 election campaign. This suspension in staking out a political position can be explained by the expectation that the area of Eastern Galicia and the Jewish minority would be granted autonomy status, an action which would deliver on an essential condition of the international agreement of Paris.

\footnotetext{
1 Brubaker 1996.

2 Polonsky 1972.

3 Jaworski 2002.

${ }^{4}$ Mendelsohn 1982.
} 
Despite the radicalisation of Polish society and the growing influence of the National Democrats, there was enough reason for the Zionist organisation to believe that its members would be able to continue to demand national and cultural autonomy for the Jewish minority. Support in the international arena and the belief in the necessity to abide by the terms of international treaties were grounds enough to believe Jewish autonomy was real. However, the promised Jewish national autonomy was not achieved, and neither was the territorial autonomy of Eastern Galicia.

Therefore, when a new electoral law was passed in July 1922, the Lviv Zionists decided to act separately. Yitzhak Grünbaum called for the creation of a national minority bloc to win the most votes possible under the conditions of the new electoral law of 27 July $1922 .{ }^{5}$ It was expected that nearly $260,000 \mathrm{Jews}^{6}$ would participate in the elections in three regions of Eastern Galicia. Still, Lviv Zionists did not support the concept of unification in the block with other minorities and announced their electoral list. This allows for the conclusion that they were certain of their popularity and were unafraid of remaining below the election threshold. They may have also assumed that a larger number of seats would be won as a result of a boycott of the elections by Ukrainian parties.

In September 1922, ZO of East Galicia announced the beginning of its pre-election campaign and formed the United Jewish Party in Eastern Galicia (Zjednoczone Stronnictwo Żydowskie w Galicji Wschodniej) $)^{7}$ which only representatives of the Jewish national minority would support. As early as on 23 September 1922, at the Zionist party congress, further steps were set: fight for protect the equal cultural and economic rights of Jews in the Second Polish Republic, solve the problem of numerus clausus, renew and reorganise the kehilla, enact land reform, and provide support for craftsmen and women. ${ }^{8}$

Within two months, from the meeting of the Party Council in September 1922 to the parliamentary elections in November, the Zionists managed to win the support of many national and social organisations: organisations of merchants, women, artisans, youth, and even representatives of the orthodox party in Eastern Galicia, Aguda Israel, whose leader, Rabbi Aron Lewin, issued a joint appeal to the local Jews together with Leon Reich. ${ }^{9}$ In the final result this party won 175,881 votes, the most among all Jewish parties that participated. ${ }^{10}$

Summing up the first nationwide elections, one may say that the results show the Zionist Organization of East Galicia was successful among the local Jewish community. It proves that in 1918-1919, Eastern Galicia became a region where the traditional Jewish society very quickly transformed itself into a vital political force. ${ }^{11}$

5 "Blok mniejszości narodowych," Chwila, 20 August 1922, no. 1250: 1.

6 “Ordynacja wyborcza a Żydzi," Chwila, 9 August 1922, no. 1240: 4.

${ }^{7}$ Mendelsohn 1982: 214.

${ }^{8}$ Komunikat Chwila, 23 September 1922, no. 1280: 1; (1922) “Żydzi!” Chwila, 27 September 1922, no. 1282: 1; “Żydzi," Chwila, 23 October 1922, no. 1307: 1.

9 “Z ruchu wyborczego,” Chwila, 18 October 1922, no. 1302: 3; “Żydzi!” Chwila, 2 November 1922, no. 1312: 1 .

10 Jaworski 2002: 17

${ }^{11}$ Mendelsohn 1982: 104. 
The results of the nationwide elections also showed that it was not possible to merge Jewish political parties within one centre in Warsaw, as planned by Yitzhak Grünbaum. ${ }^{12}$ Moreover, these elections showed divisions even on an ideological level among representatives of the centrist Zionist parties, which, later on, strongly affected the political position of the Jewish representation in the Polish Sejm (the lower house of the Polish Parliament) and Senate. The 1922 political campaign brought success for the Galician Zionists: the united coalition won 15 seats (nine delegates were from ZO of East Galicia) in the Sejm and seven in the Senate (three senators were from ZO of East Galicia). The victory of this many MPs to the Sejm was made possible not only by active voting, but also by the boycotts by Ukrainians in three regions.

\section{The Jewish Club, the national discourse and economic crisis}

The Jewish Club, created in December, 1922 was the only institutional body acting at the parliamentary level and representing the interests of the Jewish minority in the government. It was composed of 34 representatives representing the interests of 3 million Polish Jews, where the Lviv and Warsaw Zionists collected the most seats and played the most critical role in The Jewish Club's activity. However, according to Yitzhak Grünbaum, the Jewish Club had been monopolised by the East Galician Zionists since 1923, when Leon Reich was elected as its head.

Permanent conflicts between the Warsaw and Galician factions over a possible resolution to the Jewish question in Poland were of a practical and tactical nature. Disregarding these internal disputes, the Lviv Zionists managed to win the majority of votes for their crucial project: Polish-Jewish talks as early as 1925 . It was aided by further economic and political difficulties encountered by the government of Władysław Grabski.

From the onset, the Polish government was in no hurry to fulfil its obligations following the agreement on the rights of national minorities. The Poland created in 1918 had a multitude of other issues to solve. The main task facing the government was to create a unified state with national economic, transportation, communications, judicial, educational and taxation systems.

Therefore, the main focus of strengthening power in Poland was manifested in the process of centralisation and careful economic planning. It was in these spheres that many misunderstandings between the Jewish Club and the governments arose as to the desired form and shape of the financial and economic spheres of Poland. All these newly introduced government provisions were characterised by inflation and a weak currency, a typical situation for young countries. ${ }^{13}$ The government's forced centralisation of the economy negatively affected the private sector in terms of trade and crafts, a third of which was in Jewish hands. The situation was catastrophic: small Jewish artisans, who

12 In historiography this is best highlighted by the Minority Bloc as a core of the national minorities struggle against the new law, which imposed a higher percentage point to enter the Parliament. Despite the risks, the East and West Galician Zionists did not enter the Bloc, and they launched their own electoral campaigns.

13 Minutes of the Executive Committee Meeting; CDIAL, Fond 338, desc.1, case 15 (1923). 
had not yet recovered from the turmoil of war, were obliged to pay very high taxes amid rampant inflation.

And while Jews were only part of the trade and industry sector, which allowed members of parliament (MPs) and senators to coin the term "economic anti-Semitism," another segment of the population was non-Jewish. Despite this, the financial condition of Jewish entrepreneurs was deteriorating due to economic anti-Semitism: the calls from the National Democrats "for their own" (swój do swego po swoje). From 1923, MPs of the Jewish Club at plenary sessions of the Sejm and the Senate tried to convince other MPs about the fatal tactics of the Grabski government. ${ }^{14}$

Of all the state's problems, the looming economic collapse was the greatest threat to the existence of Poland. Successive governments tried to handle the necessary tasks of creating a single internal market and currency, rebuilding the economic potential after the devastation of war, establishing international economic contacts, and obtaining foreign contributions to the Polish economy.

However, the most crucial factor was the interference of the state in the economy: the nationalisation of the economy and finance. For this reason, when in December 1924 Grabski's government took office, its primary goal was to stabilise the state budget, as that preconditioned further operations to ensure the continuation of the state. At that time, the currency, the Polish marka, was undergoing rampant devaluation. ${ }^{15}$ In February 1925 , the government succeeded in stopping the inflation and could start creating conditions for the new currency, the zloty.

On the one hand, the measures taken by the government stabilised the state budget; on the other hand, it deprived small businesses of the resources supporting their existence. In addition to high taxes, new laws monopolising five types of goods were introduced in 1924. Altogether, within the confines of centralisation and changes in state procurement for the army, the tanning industry and leather product industry were collapsing, and these were typically family-run businesses in Eastern Galicia which could not compete with the Warsaw factories. ${ }^{16}$ At the same time, the state monopoly took over the production of tobacco and alcohol, ${ }^{17}$ and the sale of textiles collapsed ${ }^{18}$ - a sphere with a high percentage of Jewish entrepreneurs. Similarly, the end of trade with Soviet Russia harmed revenues. ${ }^{19}$ Jewish delegates criticised the government's work and pointed out that the direct exploitation of Jews was causing their increasing impoverishment. Such government policies caused mass emigration of the middle class not only to Palestine but also to other countries of North and South America. ${ }^{20}$

14 “Wymiar podatku obrotowego za drugie półrocze 1923-jedna fatalna pomyłka,” Chwila, 3 April 1924, no. 1818: 5 .

15 The inflation characteristic of the young Central European states grew rapidly in Poland; when in 19181 USD $=9.8$ Polish marka, on 8 January 1925, 1 USD = 10,125,000 Polish marka. The hyperinflation skyrocketed in the summer of 1924. See Polonsky 1972: 107, 117.

16 “Upadek przemysłu garbarskiego i warsztatów szewskich w Wsch. Małopolsce," Chwila, 20 January 1925, no. 2100: 4.

17 “Ustawodawstwo i zarządzenia gospodarcze w 1924 a Żydzi,” Chwila, 6 January 1925, no. 2086: 3-4.

18 “Dookoła przemysłu i handlu włókienniczego," Chwila, 27 January 1927, no. 2107.

19 "Zgubna polityka gospodarcza," Chwila, 29 January 1929, no. 2109: 2.

20 "Ilu emigrantów daje miesięcznie Małopolska Wschodnia i udział Żydów w emigracji," Chwila, 24 September 1925, no. 2342: 5 . 
Another critical moment of the stagnation of the Jewish economy was the difficulty in obtaining the credit necessary for maintaining trade and craft industries. Along with the economic policy of the government limiting the options available to Jewish entrepreneurs, the society of Lviv merchants launched a campaign of general support for the creation of the Polish Bank, an institution that was to secure financial stability in the country. In March 1924, at the convention of merchants of Eastern Małopolska, a resolution was adopted supporting the state-owned bank. ${ }^{21}$

However, forming a bank, stabilising the internal market, and slowing down inflation did not change the difficulty in securing loans - raising or receiving money remained as tricky as it ever had been, in particular in remote Galician towns. The Jewish Club actively reported in the Sejm and Senate that Jews who dealt in trade and crafts were on the verge of bankruptcy, and that the underlying cause was the state's tax policy. On the other hand, however, this harsh state policy influenced the formation and strengthening of self-organisation of professional cooperation among the Jewish middle class, ${ }^{22}$ while a small number of poor Jews experienced its adverse effects.

In addition to the dire economic situation, when discussing the new state budget Leon Reich emphasised that fiscal law not only adversely affected Jewish merchants and craftsmen. He took up the problems arising from ignoring the national and social interests of the Jewish minority, in addition to the compulsory Sunday rest and limited access to higher education. ${ }^{23} \mathrm{He}$ also drew attention to the discrimination against Jews in admissions to the official service, restrictions on the rights to practice free professions, no improvements in the fate faced by Jews in the army, as well as the lack of subsidies for education and the prohibition against the use of Hebrew and Yiddish in public which continued in the former Austria-Hungarian territory. ${ }^{24}$

The economic and financial situation in Poland was relatively stable, but the country remained poor and could be potentially improved by foreign investment. ${ }^{25}$ Despite the worsening attitudes towards Poland at the Paris Peace Conference in 1919 resulting from an appeal of the American Jewish delegation to enact sanctions against Poland for anti-Semitic pogroms in $1918-1919,{ }^{26}$ by the middle of 1925 expectations of the Polish government for investments from American Jews already seemed quite realistic. Such a pattern had already been applied in Lithuania, where Jews had autonomy and their own

21 “Kupiectwo lwowskie wobec Banku Polskiego," Chwila, 3 March 1924, no. 1784: 3; "Ustawodawstwo i zarzędnienia gospodarcze w roku 1924 a Żydzi," Chwila, 6 January 1925, no. 2086: 3-4.

22 Report; CDIAL, Fond 338, desc. 1, case 75 (1926-1932).

23 Jaworski 2002: 21.

24 Jaworski 2002: 22.

25 In that period, state investment projects and private business development were based on financing coming from America. In July 1920, Wincenty Witos thanked President Wilson for the American help. At the time, the attention of the US media and the international community was focused on Poland because of the Polish-Soviet war. Hugh Gibson, the US ambassador, who was managing the American financial aid (with interruptions) between 1919-1924, in his reports addressed to the State Department was continuously mentioning the absence of organised anti-Semitism and lack of evidence confirming pogroms in Poland; that won him heavy criticism from an American Zionist, Luis Marshall. In: Parafianowicz 2014: 159-173.

26 The American Jewish Congress together with the Committee for Protection of Jews in Poland and Eastern Europe published in 1919 a collection of materials and accounts of eye-witnesses of pogroms in Poland and Ukraine: Evidence of pogroms in Poland and Ukraine: documents, accounts of eye-witnesses, Proceedings in Polish Parliament, Local Press etc., New York, 177 p. 
ministry. However, the increasing anti-Semitism and worsening political mood in Poland ruled out the possibility of creating a Jewish ministry. Moreover, such a precedent would necessitate the creation of ministries for other national minorities, which went against the ideological assumptions of the existing political order of the one-nation state.

Moreover, the issues of national minorities remained unanswered against the expectations of the League of Nations. Therefore, the spectre of an agreement with the Jewish minority was supposed to improve Poland's position in the international arena: its borders were still not recognised by the League of Nations, and this could also help in obtaining a loan that would reverse the economic decline. ${ }^{27}$

At that time, despite the apparent successes in economic stabilisation, the Grabski government was losing the support of the parliament. As a result of political and ideological problems, the government faced with being dissolved and re-formed. It was a non-party government with weak parliamentary support. Therefore the prime minister began to seek support from other MPs, in particular in the face of the growing influence of the right-wing parties, who won 125 seats out of $444(28 \%)^{28}$ in the 1922 elections and represented the most significant and consolidated opposition force in parliament.

The Jewish representation in the parliament was large enough to secure the existing government in the face of the growing influence of the National Democrats. In turn, the National Democrats were not satisfied with the tactics of the Grabski government and their ethnic rhetoric was gaining them even more support among the public. Under such conditions, the Grabski government, looking for allies in parliament, sat down to talks with the Jewish Club. A possible agreement with this group would also be a geopolitical success, as it would help attract the expected foreign investments.

The Polish government was challenged by many circumstances which were to lead to the autonomy expected by the Jewish deputies. Everyone could understand the pragmatic expectations of the government. Grabski needed support in the Parliament, internationally, and from potential investors such as American Jews. The press was writing about the plans and benefits for the government. The necessity to rely on the American position was no secret. ${ }^{29}$ Under these conditions, a real opportunity emerged to change the Polish-Jewish coexistence. And, while the economic situation of the Jews was not improving as the state economy was stabilising, for the Jewish MPs the talks represented an attempt to achieve the expected autonomy. Leon Reich was therefore prepared to compromise.

From the very beginning, the Jewish community was in a clash of ideas about these talks. The most apparent opponents were the Warsaw Zionists. The possibility of signing the agreement was thus conditioned by the fact that, in early 1925, the Club was reorganised as Yitzhak Grünbaum, the leader of Jewish Zionists in Warsaw, had resigned and relocated to Palestine.

Under these conditions, the Grabski government began talks with representatives of the Jewish Club in the spring of 1925. The Lviv Zionists were ready to take advantage of this situation and find a compromise to achieve the expected improvement: they provided support in the Parliament in exchange for solving some critical issues of Polish

\footnotetext{
27 Mendelsohn 1982: 302.

28 More on the Parliamentary statistic in 1922 in: Polonsky 1972: 103.

29 Jaworski 2002: 27.
} 
Jews. At a press conference in June 1925, Leon Reich emphasised that these talks were to resolve Jewish issues in Poland and thus secure equal rights for national minorities. It reflected the essence of realpolitik, the realism of the Austrian Parliament.

The necessity for both sides to sign the agreement was evident, especially considering its background situation - even during that time when the public was eagerly following the sensational case of Władysław Sztaiger, a Jew accused of attempting to assassinate President Stanisław Wojciechowski ${ }^{30}$ - talks between the two sides continued. Interestingly, reaching an agreement with Jewish deputies was so crucial for the government that it was the government itself that initiated involving Ljusen Wolf and Natan Sokołów, who were staying in Warsaw at the time, into the debate. ${ }^{31}$

The press was informed about the signing of the agreement on 4 July 1925. The expectations for signing the Polish-Jewish speech were considerable: it was seen as the beginning of a new era of coexistence between Poles and Jews. After the agreement was announced, the Jewish community newspaper columns oozed with congratulations and euphoria for a month. ${ }^{32}$ Leon Reich received congratulations and support not only from the local Zionists, but acclaim was coming in from New York as well, calling the agreement "The Great National Victory of Jews in Galicia." 33

It may be assumed that the dispatching of representatives of both sides to the US played a crucial role in the quick signing of the Polish-Jewish agreement. Leon Reich made a long trip to the USA and Canada related to his Zionist and parliamentary activities. At the same time, Minister Aleksander Skrzyński went to seek financial help from American Jews. Therefore, signing the Polish-Jewish agreement before their departure was significant for both sides, ${ }^{34}$ and the Polish government at that time was in no rush to implement the terms of the agreement. One of the reasons why Skrzyński's mission was unsuccessful was the poor timing of the visit. One of the influential American Zionists, Samuel Lamport, mentioned in a letter to Leon Reich the minister's attempts on the issue to cooperate with Jews and the Americans and his meeting with Louis Marshal, the leader of the American Zionists. ${ }^{35}$

Therefore, to state that "the agreement was valid only in America"36 was, in fact, fair. On the one hand, the Polish government was unsuccessful in obtaining a loan, and Leon Reich attempted to show the success of this agreement during his stay in America and Canada, unaware that back home the government was ignoring all the resolutions of the Jewish Club.

While the Polish-Jewish agreement was being celebrated in America, there was constant criticism in Poland over the agreement. The situation deteriorated in September 1925 with the beginning of the new academic year, when it became apparent that restrictions against the Jewish minority had increased. ${ }^{37}$

\footnotetext{
${ }^{30}$ Mendelsohn 1982: 304.

31 Ibid.: 306.

32 CZA, sign. A14/22 Telegram z Kołomyi do posła Leona Reicha.

33 Ibid., Telegram z Nowego Jorku do Leona Reicha.

34 Mendelsohn 1982: 302.

35 CZA, sign. A14/3 Letter from S.C. Lamport to Leon Reich, 26 June 1925.

36 Mendelsohn 1982: 306.

37 Ibid.: 307.
} 
While the terms and deadlines for the implementation of the agreement completely failed, the fact that it and its provisions were not being implemented sparked further discussions in society, especially among radical nationalists who called the agreement "a worthless piece of paper." I suppose that the absence of Reich, who was the crucial initiator, allowed the Grabski government to ignore the need to implement its provisions, in particular after the minister returned from America without funds.

\section{The Jewish Club after the 1925 agreement and the change of its national discourse}

In October 1925, Leon Reich himself, having returned from his trip, noted that he did not expect the agreement to be quickly fulfilled. Although the criticism against the agreement was particularly strong and its ineffectiveness particularly evident at the time, Leon Reich stated that "the pact being implemented or not, it marked the beginning of a new era of Polish-Jewish relations." 38

The situation in the Jewish Club changed in November 1925. Yitzhak Grünbaum returned from Palestine, and the Warsaw faction was again able to resist the rhetoric of Lviv Zionists. The authority of the latter was severely shaken by the criticism that continued over the past four months. ${ }^{39}$ The problematic situation continued until the next meeting in February 1926, when Leon Reich and Henryk Rozmarin resigned from their positions in the Jewish Club. At the same meeting, Yitzhak Grünbaum and Ignacy Schiper demanded the cancelation of the Polish-Jewish agreement, but they were outvoted by a majority of the deputies. ${ }^{40}$ There was therefore a split in the national discourse of the Jewish minority, as the nationalism of Russian Jews replaced the nationalism of Austrian Jews: Yitzhak Grünbaum, who was at the forefront of criticising the Polish-Jewish agreement, gained complete support and never lost it.

Later, the Galician Zionists sought to reverse the imbalance in the Jewish Club by reorganising its governing apparatus. Leon Reich proposed creating a leadership of three,,$^{41}$ which would deprive any side of a monopoly. Such a proposal was to secure a balance between the various political groups within the Jewish representation. However, this was not achieved. Losing critical positions in the Jewish Club, the Lviv Zionists also lost the opportunity to expand their political discourse beyond the borders of Eastern Galicia. Similarly, in relation to the May coup in 1926 and the beginning of Poland's loss of its democracy, Leon Reich announced a change of tactics: the Galician Zionists moved to the local level. It was the beginning of a new stage in the political activity of Galician Zionists, one focused on the development of municipal self-government bodies.

${ }^{38}$ CZA, sign. A14/3, Marion Weinstein "Dr. Leon Reich, Jewish Statesman, Here on First Visit to America" The Day, 11 October 1925.

39 Ibid.

${ }^{40}$ CZA, sign. A14/3 "Dr. Leon Reich Resigns from Presidency of Club of Jewish Deputies," The Day 5 February 1926.

41 The idea was linked with the crisis suffered by the general Zionism in Poland. In the interwar period, attempts were made to solve the crisis by creating a single institution of four local Zionist organisations. 
The decision of the Galician Jews to come closer to the government in 1925 was a choice of realists. Apart from the subsequent active criticism in the press, the Jewish MPs risked nothing that could diminish the status of the Jewish minority in Poland. For the Jewish population of the early 1920s, suffering from economic and social constraints, even small concessions from the government could lead to improvements.

The several months of harsh public criticism in the press, which deprived the Lviv Zionists of influence in the Sejm and Senate, resulted more from ideological hostility, as with regard to real consequences the Polish-Jewish agreement was quite a safe and expected prospect. If it were implemented, it would be an opportunity to offer more and better conditions for the self-organisation of the Jewish minority; it would improve the geopolitical situation of Poland and, potentially, contribute to dialogue with other national minorities.

\section{Conclusions}

The political activity of the Jewish Club in 1922-1926 clearly shows how several scenarios and variants on the national question can co-exist within one nationality. And depending on the one more active in the public sphere, it will the one creating the public image about the national interests of a nation.

The Lviv Zionists were unable to pursue their tactics in the parliament over a more extended period. For this reason, after a failed agreement of 1925, and losing their influence in the Parliament, they also lost the opportunity to extend their plan to improve the conditions of the Jewish minority. On the other hand, Grünbaum's radical and uncompromising discourse became dominant in society and in historiography.

The expected "new era" and the solution to the Jewish issue in 1925 did not arrive. On the one hand, no government succeeded in solving the problematic situation, which included many economic, political and cultural limitations on the Jewish minority. On the other hand, the factors of the financial crisis of 1924-1925 had an irreversible impact on the transformation of the environment: Jewish nationalism was activated not only at the organisational level with the radical Zionism emerging, but also locally, where the majority of society continued to understand the need to solve the Jewish question.

The high taxes and stringent credit criteria, which exacerbated the situation of the Jewish community, manifested themselves in two directions: some Jews began to actively create institutions of self-organisation, while others decided on emigration from Poland.

\section{ABBREVIATIONS}

CDIAL - Central State Historical Archives of Ukraine in Lviv CZA - Central Zionist Archives 


\section{BIBLIOGRAPHY}

\section{Primary sources}

CDIAL

Fond 338, desc.1, case15 (1923) Protokót posiedzienia Komitetu Wykonawczego.

Fond 338, desc.1,case 75 (1926-1932) Sprawozdanie.

CZA

Sign. A14/3 "Dr. Leon Reich Resigns from Presidency of Club of Jewish Deputies" The Day February 5, 1926; Letter from S.C. Lamport to Leon Reich, June 26, 1925; Marion Weinstein "Dr. Leon Reich, Jewish Statesman, Here on First Visit to America” The Day October 11, 1925; Telegram z Kołomyi do posta Leona Reicha Central.

Sign. A14/22 Telegram z Nowego Jorku do Leona Reicha.

\section{Press}

Chwila 1922, 1924, 1925, 1927, 1929.

\section{Secondary sources}

Brubaker, R. (1996), Nationalism Reframed, Cambridge.

Evidence of Pogroms in Poland and Ukraine: Documents, Accounts of Eyewitnesses, Proceedings in Polish Parliament, Local Press Reports, etc, (1919?), New York: Information Bureau of the Committee for the Defense of Jews in Poland and Other East European Countries affiliated with American Jewish Congress.

Jaworski, W. (2002), Syjoniści wobec rzadu polskiego w okresie międzywojennym, Sosnowiec.

Mendelsohn, E. (1982), Zionism in Poland: The Formative Years. 1915-1926, New Haven.

Parafianowicz, H. (2014), Hugh S. Gibson's Diplomatic Service in Poland after the First World War, Biatostockie Teki Historyczne 12: 159-173.

Polonsky, A. (1972), Politics in Independent Poland, Oxford. 
